\title{
PIANO PERFORMANCE: MUSIC COMMUNICATION AND THE PERFORMER-AUDIENCE SHARED EXPERIENCE
} APRESENTAÇÃO DE PIANO: COMUNICAÇÃO MUSICAL E A
EXPERIÊNCIA PARTILHADA ENTRE O MÚSICO E O PÚBLICO

\author{
Barbara James \\ University of Queensland, Australia \\ barbara.james.phd@gmail.com
}

\begin{abstract}
Music is powerful as a social mode, and a music performance offers a compelling means of communication which reveals aspects of the performer's personality and musicianship. A pianist's creative imagination is the key driver giving music its emotional appeal, with the performance built on the score interpretation, which involves a fluid concept, so that each performer can offer a distinctive rendition. The soundtrack involves continuous interaction with the music, with musicians evaluating the quality and fit of the sounds with the dramatic concept of the score. The playing actions generating the sounds communicates the music's structural and emotional features, with these actions increasing in amplitude with the pianist's increasing skill and connection with the music. Although the aural aspect was previously considered core to the domain of music, the visual information also influences the observers' perception of the music's expressive intent, and this is important particularly for music-naïve audience members. The presence of observers during a performance provides a motivating factor for musicians, affecting the amplitude and intensity of movements which, in turn, increase the audience engagement with the playing. At this level of performance, skilled musicians sense the playing movements as intrinsically rewarding, and undergo a state of effortless attention and high arousal which generates in them a subjective state of optimal experience. Sensing the musician's connection with the music engages the attention of audience members, forging a bond between them which results in neural activity in the same brain regions of both, enabling a sharing of
\end{abstract}


the affective experience. Successful performance communication involves the performer capturing the imagination of an audience, and this review explores the different performance elements shaping the communication of music and conveying the music's expressivity, and the features that affect observers and enhance their enjoyment of the music. The review concludes with an examination of the performance appraisal process.

Keywords: music communication; creative imagination; shared affective experience; aesthetic appreciation; mirror neuron system.

\section{Resumo}

A música é um poderoso mecanismo social, e uma apresentação musical é um atraente meio de comunicação que revela aspectos da personalidade e musicalidade do artista. A imaginação criativa de um pianista é essencial para dar apelo emocional à música, com a apresentação sendo construida a partir de sua interpretação, o que envolve um conceito flexível, para que cada artista possa oferecer uma interpretação distinta. A trilha sonora envolve interação contínua com a música, com os músicos avaliando a qualidade e o ajuste dos sons ao conceito dramático da partitura. Os sons gerados pelas ações realizadas enquanto a música é tocada comunicam suas características estruturais e emocionais, aumentando a amplitude dessas ações ao passo em que a habilidade e a conexão do pianista com a música aumentam. Embora o aspecto aural fora anteriormente considerado fundamental para o domínio da música, a informação visual também influencia a percepção dos observadores sobre as intenções expressivas da mesma, e isto é importante especialmente para públicos mais ingênuos. A presença de observadores durante uma performance é uma motivação para os músicos, afetando a amplitude e intensidade dos movimentos que, por sua vez, aumentam o engajamento do público com a apresentação. Neste nivel de apresentação, músicos qualificados sentem uma gratidão intrínseca enquanto tocam, entrando em um estado de atenção sem qualquer esforço e grande excitação, o que gera um estado subjetivo de experiência ideal. Sentir a conexão do artista com a música envolve 
a atenção da plateia, forjando um laço que resulta na atividade neural nas mesmas regiões cerebrais de ambos e permitindo uma partilha da experiência afetiva. Comunicação do desempenho bem-sucedido implica na captura da imaginação da plateia pelo artista, e esta análise explora os diferentes elementos da apresentação, dando forma à comunicação e transportando a expressividade da música e as características que afetam os observadores e melhoram sua apreciação da performance. $\bigcirc$ estudo conclui com uma análise do processo de avaliação da apresentação.

Palavras-chave: comunicação musical; imaginação criativa; experiência afetiva compartilhada; apreciação estética; sistema de neurônios-espelho.

\section{Introduction}

Music, with its potential to convey emotion, influence mood, and induce observers to move to its rhythm, offers a reason for both producing and listening to it, in addition to fulfilling a basic social need for communication with others (AMODIO; FRITH, 2006). A musical performance offers a compelling opportunity for people to unite with others with whom the experience is shared, as the sharing of such experience is the essential ingredient for social and emotional interaction (KOELSCH, 2O/4). Accordingly, musicians should focus on how to involve observers, so they comprehend and appreciate the unfolding musical text, making it important to consider what audiences value in a musical presentation. A successful performance means engaging the emotional faculties of observers because a primary goal for performers is to create an affective resonance with their audience (VAN DER SCHYFF, 2013). A vital feature of music's appeal is that, although the pianist's movements provide the initial impetus for the music from the production of the first musical sounds, each affects the other, instigating a symbiotic relationship between the two that allows for flexibility and spontaneity in the pianist's response to the unfolding soundscape.

A pianist's potential for imaginative and innovative thinking gives music its aesthetic appeal and, combined with his/her relationship with the piano and understanding of its dynamics, enables the shaping of 
the soundscape to match the music's mood and emotional texture. The score's structural features and expressive content generate the warmth and character that makes the musical experience enjoyable while evoking heightened emotions in performers and promoting a sense of the pianist's connection with the music, which resonates with the audience (OVERY; MOLNAR-SZAKACS, 2009). With increased exposure to the score, the musician's insight into the imaginative opportunities in the notation expands and the interpretation adapts, so that music is not ever a static entity but rather a creation that unfolds in time. In this changing environment, pianists respond to variations in the underlying themes so, as well as producing the playing technique, they control the character of the narrative as it adapts to keep its creative focus (BRATTICO; PEARCE, 2013). The dynamic relationship between the performance elements is so appealing in the music because it adds to the spontaneity to the performance. Interestingly, both Chopin and Liszt were concerned with the performance aesthetics and held that playing should have a 'spontaneous and almost improvisatory character, delivered by a playing style with no stiffness or overt tension' (CERIG, 1974, p. 180).

A musical performance is, above all, an interactive and participatory medium with both performer and audience actively engaged in listening and reacting to the flow of musical sounds and to the pianist's movements. Moreover, audiences generally anticipate a distinctive event (CLARKE, 2006), and performers incorporate their expressive originality into the interpretation through their timing and intensity patterns, articulation, pedaling, and overall sound quality (CINCRAS et al., 2011; REPP, 1992). These last decades have yielded valuable research on the different facets of performance communication, and they are examined in this review from a bilateral perspective of how performers present the structural and emotional information which provide the basis for the music; and what it is about the communication that helps observers to perceive the significance of the musical text, so they can mentally participate in it and enjoy the performance (CHRISTENSEN et al., 2014). These issues provide the backdrop for an exploration of how: the auditory and visual information blend together to influence audience comprehension and appreciation of an evolving interpretation; the performer and audience each become engrossed in the performance to produce a connection between them, involving neural processes by which a performer also generates creative 
ideas and images of the music. By bringing together the elements contributing to the performance, the overall goal of this multidisciplinary review is to support our understanding of the performance process itself and its potential to create a shared affective and aesthetic experience linking pianist and audience.

\section{Main contribution}

This section considers performance communication through the score interpretation and the structural and expressive features forming its framework, as well as how they are conveyed by the musical sounds and expressive movement patterns; impact of the aural vs the visual information on the audience perception during a performance, and their differential effect in influencing audience understanding of the affective meanings in the music; and the effect of the heightened arousal of pianists while performing and engaging the observers, resulting in a shared affective experience, and its neural basis via the mirroring function which is also involved in a performer's facility for imaginative thinking.

\section{Performance communication}

A defining characteristic of a musical performance is that it implies the presence of an audience; thus, the primary purpose of effective music communication is for pianists to convey the music's storyline to engage the audience by focusing their attention on affectively significant information in the musical text. The platform on which music communication is built is the score interpretation, with a musician developing a concept of the score's dramatic context and, during early practice sessions, making decisions on the structural architecture and moods elicited (SEASHORE, 1938). The repertoire choice is important because the act of performing means assuming a stage persona in representing the narrative, in telling its story, so the music must metaphorically 'speak' to the pianist (VILA VERDE, 2007). The interpretative process is dynamic, with inevitable changes over time and requiring a spontaneous response from pianists (CHAFFIN; LEMIEUX; CHEN, 2004) through a flexible readiness in the playing movements to reflect the feelings elicited by the music as it is played. The score's notation is based on a generative grammar, giving musicians the opportunity to shape their interpretation by filtering their musical ideas through their 
past musical experience and their creative imagination, enabling them to convey their own 'voice' and expressive style to the performance (CLARKE, 2005; 2006). 'Creativity' is linked to expressiveness and involves the pianist's ability to conceptualize the score's expressive features in novel ways through risk-taking and innovative ideas (CIBSON; FOLLEY; PARK, 2008). It is conceivable that creativity is also in the 'ear' and 'eye' of observers, influencing how they perceive the expressive playing, with them processing the aural and visual information through a filter of their own musical preferences and performance expectations (CRACHTEN; WIDMER, 2012). The fundamental way performers demonstrate their individual style is by articulating the sounds to reflect the impact of the score's structures as befitting their overall vision of the piece, and by playing movements that reinforce the meanings in the sounds to reflect the music's expressivity.

\section{Performance communication - aural and visual cues}

Pianists both generate and react to the musical sounds, which reflect their perception of the scores structural framework and changing moods. By actively listening to the sounds and matching them with the aural images created against a backdrop of previously experienced musical events, they articulate their response in the sounds that follow (REPP, 1992; ZATORRE, 2012). Phrasing provides the basic architecture for the score interpretation, with each unit distinguished by an elongated time interval at its beginning, and a longer interval signaling its end. The shape of a phrase is defined by a slight pause before the climactic note, which denotes a change in intensity patterns from an increase towards the climax to a decrease after it (DAVIDSON, 2002; SHODA; ADACH, 2012). As a plastic unit, each phrase is open to a pianist's interpretation as the performance evolves, making them also a vehicle by which pianists express their personality and aesthetic (SEASHORE, 1938). The audience is informed of the score's expressive features by different temporal strategies and intensity patterns, and musicians have a distinct style in varying accent note length, inter-onset intervals, and using chord asynchronies (DAVIDSON, 2012; MACRITCHIE, 2015). Performers modulate individual sounds to add texture and character to a note sequences through expressive variation in tone timbre, which is an essential feature of the communication of emotion, by instinctively manipulating touch through finger/key pressure intensity and duration allied with pedaling (BERNAYS; 
TRAUBE, 2011; PALMER, 1997). All sound artifacts allow for spontaneity in the musical expression and reveal idiosyncratic characteristics associated with a pianist's playing style, with the use of expressive timing and patterns of timbral expression, also directly related to the skill level and musicality of the performers (BERNAYS; TRAUBE, 2014; JUCHNIEUICZ, 2008).

Expressive body movements emerge spontaneously during musicmaking to emphasize emotionally-significant features and enhance the impact of the aural information (RODCER; CRAIC; O'MODHRAIN, 2012) and facial expressions which, allied with head movements, provide key signals of expressive intent and draw attention to acoustic features such as consonance and dissonance, pitch structure, and phrasing (DAVIDSON, 2012; THOMPSON, 2011). Audience appreciation is influenced by the amount of time a pianist leans forward, and the number of directional changes in trunk movements such as swaying, which is used almost universally by pianists to provide important landmarks and enhance the performer's artistic interpretation (DAHL; FREEBURG, 2004) by defining cycles of tension, indicating phrase boundaries, and clarifying the score's structural architecture (DEMOS; CHAFFIN; KANT, 20 I 4; WANDERLEY et al., 2005). Trunk/ head movements increase in frequency as the emotional intent of the music becomes more intense (DAVIDSON, 2012) and contribute to the playing technique through the transfer of the momentum developed by the upperbody movement and its associated musculature when building tension, which is delivered to the fingers to increase the force needed for the keystroke, particularly with the high sound-level playing needed in a large concert space (FURUYA et al., 2010). Playing movements cannot be divided into being either sound producing, expressive, or 'ancillary' because as movement is continuous, it is difficult to tease the functions apart, and motor programs expand to meet both technical and expressive goals and, thus, are dynamic in responding to the player's impulses and feelings (SCHMIDT; LEE, 2005).

Arm and hand playing movements are viewed as transmitting grace and beauty, with audiences responding positively to the arm being active through frequent use of hand lifts, wrist undulation and elbow rotation, described as 'elbow choreography' (BERNSTEIN, 1967) because it appears that the elbow traces the contour of the music as it is played (DAVIDSON, 2012). These arm/hand movements are generated in producing the playing technique, with spontaneous hand 
lifts occurring as a reaction to the key force transmitted in the keystroke (FURUYA; OSU; KINOSHITA, 2009). Also, because the feelings evoked by the musical sounds coalesce in the fingers, these movements may also reflect the passion experienced by the pianist. Elbow rotation results from forearm circumvolution because of the wrist, forearm, and elbow acting as a dependent unit in a rotation. In positioning the hand/fingers for a keystroke, inward hand rotation causes the upper-arm/elbow to move outward and vice versa, and in skilled pianists, the rotational movement is continuous, with serial changes in finger positioning. Arm/ hand movements aid expressivity by drawing attention to the musical sounds and, when combined with other cues such as head nods, trunk movements, and sound effects, including expressive temporal variation and changes in the tension level, help to define the musical meanings, thus clarifying the audience perception (VUOSKOSKI et al., 2014). As observed by Jane Davidson (2012) in her examination of expressive playing, "performance skills involve the biomechanical aspects of sound production and coexist with facial expressions and body movements that elucidate the implications of the musical text". The amplitude and duration of trunk and arm movements expand with growing technical mastery of the score's notation (RODCER; CRAIC; O'MODHRAIN, 2012) and when playing in front of an audience (SHODA; ADACHI, 2O12), indicating that the ambience produced by sharing the performance space with others creates an emotional-affective response in the performer, which, in turn, enriches audience perception of the musician's artistry and influences their overall ratings of the musical performance (JUCHNIEUICZ, 2008).

\section{Perception of performance - interaction of aural and visual cues}

With the invention of the radio and gramophone recordings, music came to be considered an aural phenomenon (THOMPSON; CRAHAM; $\mathrm{RUSSO}, 2005$ ). However, the newer use of video recordings meant that the relationship between auditory and visual information could be studied through the use of sound- or visual-only recordings, by separating them for listeners/observers. It was established that the pianist's movement patterns and facial expressions, even without sound, were influential in focusing listeners' attention on critical acoustic information and variation in emotional content, expressed through the rise and fall of tension levels, which was more easily assessed through the movement patterns (SHODA; 
ADACHI, 2012; VINES et al., 2011). When novice and expert listeners were asked to choose competition winners (already decided by judges), all observers selected the actual winners when based on movement recordings, whereas neither group could identify the winners based on sound alone (TSAY, 20 I3), with the implications of these findings extending to the professional judgment of performance at auditions or competitions. However, separating sound and movement in this way involves an artificial concept because neuroscience research has shown that performance observation is multisensory, with fast and integrated auditory, visual, and motor processing - a constant background process, organizing the unbroken stream of sights and sounds perceived simultaneously into an articulate perceptual experience of the event (ZATORRE; SALIMPOOR, 2013). In addition, it also appears that pianism is the only musical or artistic discipline in which this question has been asked, and now, perhaps, it may even be that the importance of movement is overestimated in comparison to the musical sounds, without which there would be no music. When the 'live' performance was compared with its 'recorded' counterpart, to study the effect of context on performance, differences were apparent in the audience perception. The real-time version was appreciated as being more artistic and expressive, partly because the performer responded to the presence of an audience with clearer contrasts in the expressive movements and due to the soundtrack, suggesting that sharing the experience affected the intensity of the performer's response due to the growing connection between the audience and performer (SHODA; ADACHI, 2012; TSAY, 2013). The powerful effect of visual perception also flows over to a performer's entrance to the front stage, when the first impression is important because, if viewed positively, audience enthusiasm for the performance to continue increases, influencing audienceexpectancy of a meaningful and interesting rendition (PLATZ, 2013).

\section{Listener/observer's difference in perception}

Audiences are composed of people who vary in their sensitivity to different aspects of the performance, and performers need to be aware of the differences between audience members that might occur, even though they are hearing/seeing the same musical input. Observers differ in their impression of the relative duration of musical sounds and intervals between sequential notes and referred to as a 'musical illusion' that causes 
the individual's perception to expand or contract in relation to actual physical time (SCHUTZ; LIPSCOMB, 2007). Time perception is affected by the associated movement quality, and whether it harmonizes with the observer's mood elicited by the music (DAVIDSON, 1993). Accent note duration is affected by the scope and duration of movements producing the sound (ARMONTROUT; SCHUTZ; KUBOVY, 2009) with the magnitude of expressive temporal variation perceived more accurately if movement patterns also expand (VINES et al., 2011 ). The duration of post-impact motion is also important (ARMONTROUT; SCHUTZ; KUBOVY, 2009) so that the follow-through movement after the keystroke is not inhibited in its scope but allowed to flow naturally. Similarly, the extent of silences is influenced by the duration of the preceding movement event, with pauses following playing gestures involving more movements, perceived as longer than those requiring less activity (JIA, 2013; MARCULIS, 2007).

Observers, with or without prior musical training, also differ in the way they engage with music. Musically-trained observers have a pitchand timbre-processing advantage (BERNAYS; TRAUBE, 2014), a greater sensitivity to expressive temporal variation (VINES et al., 2011), to the degree of difference between expressive levels (DAVIDSON; CORREIA, 2002), and an increased capacity to identify structural features from the musical sounds (BHATARA et al., 2011). These observers concentrate on the melody and tempo, whereas the other group is more concerned with the dynamic range, indicating the importance of varying the sound level for this group (JUCHNIEUICZ, 2008). It is not surprising that musically untrained listeners rely more on expressive movements that reinforce the sounds to appreciate their significance and impact on the musical story, as movement cues also help in making judgments about the musical meanings faster (DAVIDSON; CORREIA, 2002). On the other hand, when judging skill level, both musically -experienced and naïve observers are similarly accurate in performance appraisal (RODCER; CRAIC; O'MODHRAIN, 2012).

\section{Shared affective experience and the neural response}

The special feature of a musical performance that makes it an effective communication system is the sharing of an affective and aesthetic experience between a performer and the audience in the distinctive setting of a concert space through a common understanding 
of the sounds and the expressive body language conveying the musical ideas (HASSON et al., 2012). The link between this performance partners is explained by the encoding of the experience in both performer and observers through neural activities in anterior brain networks associated with reward, motivation, emotion, and arousal (CALLESE, 2003). This phenomenon was labelled a 'mirroring function' when it was found that the same brain regions are activated when a person either performs an action or sees it performed (CALLESE et al., 1996), or on observing another person experiencing an emotion, one experiences the same emotion (FREEDBERG; CALLESE, 2007). Music is a language of emotion that originates in a movement-based context, and pianists experience their emotionally-driven movements as aesthetically pleasing, with the intrinsic 'feeling' of the movement being rewarding (MONTERO, 2006), resulting in a heightened focus and absorption in the playing (MAES et al., 2014; SHOUSE, 2005). Musicians' total engagement in performing is reflected in their psychophysiological state, with increases in blood pressure, heart rate variability, and rapidity and depth of breathing, as well as in changes of the facial muscles, with relaxation of the frown muscle and increased activity in the muscle promoting smiles, indicating the pleasant emotional responses to music (DE MANZANO et al., 2010).

\section{You are the music, while the music lasts. - T.S. Elliott}

The mirroring function explained how observers, stirred by the sight of the pianist in action, experience the same 'internal' sensation of performing, perceiving the movements as pleasing and enhancing their link with the pianist (MONTERO, 2006). Observers are also subject to similar psychophysiological changes as the performer in response to the emotional resonance of the performance (MANZANO et al., 2010), indicating that 'listening' to and 'seeing' a performance does not imply a passive reception of impressions but reflects an engagement with the music through the feelings aroused. Observing the actions of others means understanding the intentions and goals of the movements, which is important in music when learning new skills and duplicating them with temporal accuracy or engaging in synchronous action with others in a musical group (CATMUR et al., 2008). The discovery of trimodal (motor, visual, and auditory) neurons (D'AUSILIO, 2007) showed that the mirrormatching network maps the acoustic representation of actions into the 
motor plans necessary to reproduce the playing actions (BANCERT et al., 2006). Neural connections become stronger the more frequently the actions are repeated, with changes apparent after 20-30 minutes of training, highlighting the functional plasticity within this system (HASSON et al., 2012).

The neuron mirror system (NMS) also explains the capacity for empathy, which involves both sharing emotions (feelings, sensations) and understanding the expressive intentions of others, making it essential for the unconscious sharing of the affective experience (CARR et al., 2003). Empathy is important for the pianist-interpreter in sensing the emotion in the musical structures and properly responding to them and, for observers, in shaping their aesthetic understanding of the emotions in the music (CARR et al., 2003). However, people differ in their sensitivity to feelings expressed by others (JABBI; SWART; KEYSERS, 2007). It is the ability of music to convey affective information through the evocative powers of the sound track and expressive movements that makes it an engaging form of communication, with the performance-related movements reflecting the pianist's emotionally-charged involvement in the music, the crucial component in performance communication (BRATTICO; PEARCE, 2013).

\section{Discussion}

A musical performance is a compelling multi-modal interactive activity that enables musicians to involve their listeners/observers in their music-making, creating a connection between them and rendering the question of what it is about the performance that affects observers' understanding and enjoyment of the music, that enhances their engagement with the music. A recurring theme was that a musical performance is a valuable social activity enriched by the presence of other people in the intimate setting of a concert space and that, through the common focus on the music, it affects an individual's experience (CHATEL-COLDMAN et al., 2013) and suggests that the social sharing has an impact on the experience itself (FISCHER; MANSTEAD; ZAALBERC, 2003). The social aspect of a performance implies that musicians must have an innate ability to establish meaningful bonds with their audience, an unconscious process which creates the feeling, for audience members, of 'being together', which makes music so appealing. A performer's facility for emotional empathy is another quality enriching social interaction, 
enabling him/her to understand the emotions expressed in the music and then to communicate such sensations to the audience, enhancing the connection between them (FREEDBERG; CALLESE, 2007).

\section{Music communication}

Although the aural component of a performance was formerly regarded as the vital criterion in music communication, it is now evident that a performer's movements contribute significantly to the perception of overall expressivity. Furthermore, because the sounds and expressive movements convey the same affective valence, the emotional response is modulated by their concurrent presentation, an effect known as the cross-modal bias (VINES et al., 2011). In a performance, observers simultaneously process the continuous stream of sights and sounds and meld them into a cohesive integration of aural and visual cues, to produce an articulated perceptual experience of the event (KUBOVY; SCHUTZ 2010; VUOSKOSKI at al., 2014). It is not surprising that a 'live' performance has greater impact on an audience when compared with its recorded counterpart (TSAY, 2013) because the performer's 'presence' is felt more powerfully due to the affective connection with the audience, best made through face-to-face interaction (FUJINAMI; HIDAKA; KASHYAP, 2015) which activates neural mechanisms registering emotion (FERRARI; RIZZOLATTI, 2014). Also, the greater visibility of the musician's facial expressions means that the emotional intent of the music is communicated more effectively (DAVIDSON, 2012; DI DIO et al., 2016). The cross-modal interactions of sight and sound mean that potential performers should not just focus on the musical sounds when reviewing recordings of their performances, because their self-assessment of how well they are communicating the musical meanings through their movements in tandem with the sounds will be closer to an expert-assessment (MASAKI et al., 2011).

A musical performance is built on its dynamic relationships, with the musical sounds and playing movements affecting each other (TRUSLIT, 1938, apud REPP, 1993) and, as the score interpretation evolves, key features can take on a different significance, which the pianist is able to respond with changes in the playing movements. This fluidity appeals to an audience because it portrays a performer who is involved in the presented time' and reiterates that the musician has a distinctive approach (CLARKE, 2005). Playing movements cannot be segmented into "sound producing, 
expressive, or "ancillary' constituents" (DAVIDSON, 2012) since movement is continuous and motor programs established during practice expand to meet both technical and expressive goals, being dynamic in responding to the player's impulses and feelings (SCHMIDT; LEE, 2005). As the performance evolves, a dynamic relationship also develops between performer and audience, influencing a musician's affective experience, and intensifying their emotional arousal with playing movements greater in intensity and amplitude (RODCER; CRAIG; O'MODHRAIN, 2012). The scope and duration of playing movements are also helpful to music-naïve observers in their perception of the expressive intent communicated and in discerning the duration of time-related aural events vital to the score interpretation such as accent notes and pauses (BHATARA et al., 2011). Audience members respond to the performer's immersion in the playing, increasing their engagement with the music and with the musician (COLE; MONTERO, 2007); hence, for observers 'listening' to and 'seeing' the performance involves an active reception of impressions, reflecting their involvement in the music through its emotion-based qualities (OVERY; MOLNAR-SZAKACS, 2009).

\section{Movement sensation - neural aspects}

Expressive playing movements are often considered reflective and responsive, as well as 'secondary' to the ideas and feelings the music elicits, a notion held at earlier times in history about the brain/body dichotomy with a rigid distinction between the mind and its physical manifestation (UIKIPEDIA, 2017). However, our increased understanding of the sensation of movement has led to a new perception of it as affectively rewarding in itself, and highlighting that we have a cognitive ability to derive pleasure from something as abstract as movement in space (CHRISTENSEN; CALVOMARINO, 2013), engaging performers' creative power and acting as a motivating force (CSIKSZENTMIHALYI, 1978). The pianist's movements also resonate with audience members, evoking a sense of action, particularly through movements of the head and the arms, (FREEDBERG; CALLESE, 2007) and explaining why audience members are drawn to the activity of the arms even though elicited by and explaining why audience members are drawn to the activity of the arms even though elicited by the actions needed to generate the keystrokes. Observing the pianist's movement leads to the activation of motor areas of the brain involved and to its rehearsal through the MNS (CALLESE et al, 1996). Thus, helping to explain 
why a performer's movements are intrinsically pleasing for observers and enable a sharing of the affective experience (MONTERO, 2006), also explaining the mechanism for how listeners/observers 'feel' the emotions conveyed in the music and create a performer-observer bond, shown by activation of the same neural networks in the performance partners (CALLESE, 2003). Truslit (1938, apud REPP, 1993) proposed that a musician's movements 'get purchase on observers because the brain acts as a transducer for movement', an opinion now given credence by the discovery that the MNS is multimodal with movement and musical sounds, represented in an observer by the required movement to produce the observed effects (OVERY; MOLNAR-SZAKACS, 2009).

\section{Effective communication}

Effective music communication implies that all audience members understand and enjoy the repertoire presented in performance programs. An important consideration is that musically-naive audience members respond to music with a reduced appreciation of aural cues and depend on the scope and duration of a pianist's playing movements for a clearer perception of the duration of accent notes, pauses, and ritardando, clarifying the score's structural architecture and the expressive features (BHATARA et al., 2011). Without instructions regarding the importance of expressive movement for communication, performers might focus merely on the technical correctness of movement execution, as they do for rehearsal purposes in a class (CHRISTENSEN; CALVO-MERINO, 2013). Ongoing research has been trying to identify the best methods for informing observers about the key events in a score, and both performance notes and pre-performance talks have been trialed to help observers follow the music's expressive undulations (REIMER, 2015), and this is considered especially helpful when the works performed are novel to an audience (BENNETT; CUINSBORG, 2015). As each performer best understands their score interpretation, they are eminently suited for describing the images they have portrayed in the sounds, and the passion they will undoubtedly show could be effective in engaging the audience even before the playing begins. However, whether musically-naive observers benefit from these interventions or no is yet to be tested. It also reiterates that pianists need to review recordings of the sound/expressive movement contributions to their performance in communicating the musical story, so its messages are understood. 


\section{Implications for training students}

The attributes considered important to communication - a social awareness with a need to 'tell' the musical story; a creative imagination to generate the inspiration and viewpoint that makes a performance unique, thereby fulfilling listeners' expectations; and an empathic understanding of the emotional texture of the music - imply that not all personality types might succeed as professional musicians (CIBSON; FOLLEY; PARK, 2008). Despite these perceived limitations, teaching methods should provide all young people with a development pathway to foster their musical gifts (MCPHERSON, 2015), so they can either move onto tertiary study or use their musical ability for recreation and personal fulfillment. With the importance of imaginative thinking in performance preparation and delivery, students in their early years should be provided with opportunities for applying this conceptual understanding to creative tasks in an environment that encourages divergent thinking in music (UEBSTER, 1990). It is unfortunate that the narrow vision of performance, evident in some music examination systems - especially in the reference to expressive timing and even expressive movement as 'deviations from the exact' (CLARKE, 2005), is working against the idea of presenting an expressive rendition. This because adhering to textual fidelity or strict rhythms restricts an artist's interpretation, diminishing the ideal of musicianship (SCHONBERG, 1986). Hopefully, with time a less literal-minded understanding of score interpretation will be recognized and reflected in the training of the next generation of performers in tertiary institutions. Although music performance relies on dynamic postures, movement, and creative sensibility to convey the score's musical ideas, these elements have not always received sufficient attention from music trainers. Students also deserve to understand the role of movement in association with the aural aspect in molding a rich musical experience and the affective power of music-driven movement in producing an aesthetic response involving both performer and audience.

\section{Music evaluation - competitions and auditions}

Evaluation of performance is necessary for the training of classical pianists, however, the dynamic nature of the performance elements and the lack of a standard or reliable measurement of any of the variables involved adds to the difficulty in making assessment an objective process. The effect 
of a performer's appearance on stage implies that there is a powerful social component in the way performers are perceived, making it difficult for judges not to be affected by their initial impression of a pianist (PLATZ, 2013). Other non-musical factors shown to affect performance evaluation include the performer's gender, age, and dress and manner, being virtually impossible to determine if these 'extra-performance' variables do sway the judges' decisions (WADDELL; WILLIAMSON, 2015). Judges, however, may not be able to selectively ignore input stimuli nor to suppress a natural propensity to make social judgments (WAPNICK et al., 2009). In addition, it may be difficult to clearly define the extra-musical performance variables or determine to what degree these influence performance ratings (JUCHNIEUICZ, 2008). It is also necessary to consider how examiners and judges in piano competitions are prepared for this role. The primary criterion guiding wise decision-making in piano competitions should be to promote and reward talent as a good long-term investment in the future of a musician for the sake of the music-going public. All listeners filter the ongoing sights and sounds of the performance through the prism of their own appreciation of the expressive strategies used, and judgment may be based on how open they are to accept an individualized version of a favorite composition from the concert repertoire (SCHONBERG, 1986). Judges should be carefully selected for this task, and the best place to look for advice on factors important to performance delivery could be the literature on audience perception and neuroaesthetics - a recent advance in neuroscience - which offers new insights into the affective and aesthetic processing of performance (BRATTICO; PEARCE, 2O13).

\section{Conclusion}

It is evident that the quality of the performer's dynamic movement patterns and creativity in delivering are central to the communication process, with the social aspect of the shared aesthetic experience between performer and audience being dominant in the informing performance, and leading to the question - where to now? We are at an exciting time in the performance science, with extensive research base available on all performing elements. As to the future, Seashore (1938) wrote: 'we are on the frontier of a new music, with the performer being given new opportunities', which is possible through our enhanced appreciation of the multi-dimensional elements informing the performance. Seashore also counsels that 'future progress will depend on the adoption of a scientific point of view to inform 
on movement quality', and the need for an interdisciplinary approach to this domain is growing. Similarly, research in neuroaesthetics indicates the need for an audience-based investigation, to include observers/ listeners without musical experience because it is essential to identify how we can reliably engage future audiences since this surely is our raison d'etre for performing. The remaining requirement is for those professionals to be able interpret research findings and comprehend how they can be applied to the study of music, to effectively communicate with tertiary students, lecturers, and trainers of music students to ensure that music-based knowledge evolves with the changing understanding of the mechanisms essential to music performance, assuring that we are kept at 'the forefront of music-based knowledge'.

\section{Conflict of interest statement}

The author declares that the theoretical research was conducted in the absence of any commercial or financial relationships that could be construed as a potential conflict of interest.

\section{Acknowledgment}

This multidisciplinary theoretical review is based on a presentation made at the International Symposium on Performance Science, 2015. My thanks to A. Williamon from the Royal College of Music for making these symposia a reality - I greatly benefit from my attendance, which allowed me the opportunity to meet fellow researchers.

\section{References}

AMODIO, David M.; FRITH, Chris D. Meeting of minds: the medial frontal cortex and social cognition. Nature Reviews: neuroscience, London, n. 7, p. 268-277, 2006.

ARMONTROUT, James A.; SCHUTZ, Michael; KUBOVY, Michael. Visual determinants of a cross-modal illusion. Attention, Perception, \& Psychophysics, New York, v. 71, n. 7, p. 1618-1627, out. 2009. 
BANCERT, Marc et al. Shared networks for auditory and motor processing in professional pianists: evidence from fMRI conjunction. Neuroimage, Amsterdam, v. 30, n. 3, 917-926, abr. 2006.

BENNETT, Dawn; CUINSBORG, Jane. The impact of program notes on audience responses to unfamiliar songs. In: INTERNATIONAL SYMPOSIUM ON PERFORMANCE SCIENCE, Kyoto, 2015. Abstracts... Kyoto: Ryukoku University, 2015. p. 24.

BERNAYS, Michel; TRAUBE, Caroline Verbal expression of piano timbre: multidimensional semantic space of adjectival descriptors. In: INTERNATIONAL SYMPOSIUM ON PERFORMANCE SCIENCE, Toronto, 2011. Proceedings... Brussels: European Association of Conservatoires, 2011 . p. 299-304.

Investigating pianists' individuality in the performance of five timbral nuances through patterns of articulation, touch, dynamics, and pedaling. Frontiers in Psychology, Lausanne, v. 5, n. 157, mar. 2014.

BERNSTEIN, Nikolai A. The coordination and regulation of movements. New York: Pergamon Press, 1967.

BHATARA, Anjali et al. Perception of emotional expression in musical performance. Journal of Experimental Psychology: human perception performance, Washington, DC, v. 37, n. 3, p. 921-934, 2011.

BRATTICO, Elvira; PEARCE, Marcus. The neuroaesthetics of music. Psychology of Aesthetics, Creativity, and the Arts, Washington, DC, v. 7, n. I, p. 48-61, 2013.

BROUCHTON, Mary C.; DAVIDSON, Jane W. Action and familiarity effects on self and other expert musicians' Laban effort-shape analyses of expressive bodily behaviours in instrumental music performance: a case study approach. Frontiers in Psychology, Lausanne, v. 5, n. 1201, out. 2014 .

CARR, Laurie et al. Neural mechanisms of empathy in humans: a relay from neural systems for imitation to limbic areas. Proceedings of the National Academy of Sciences of the United States of America, Uashington, DC, v. 100, n. 9, p. 5497-5502, 2003. 
CATMUR, Caroline et al. Through the looking glass: counter-mirror activation following incompatible sensorimotor learning. European Journal of Neuroscience, Hoboken, v. 28, n. 6, p. 1208-1215, set. 2008.

CHAFFIN, Roger; LEMIEUX, Anthony F; CHEN, Colleen. It's different each time I play: why highly polished performances vary. In: INTERNATIONAL CONFERENCE ON MUSIC PERCEPTION AND COCNITION, 8, Evanston, 2004. Proceedings... Sydney: Causal Productions, 2004.

CHATEL-COLDMAN, Jonas et al. Non-local mind from the perspective of social cognition. Frontiers in Human Neuroscience, Lausanne, v. 7, n. 107, abr. 2013.

CHRISTENSEN, Julia F.; CALVO-MERINO, Beatriz. Dance as a subject for empirical aesthetics. Psychology of Aesthetics, Creativity and the Arts, Washington, v. 7, n. 1, p. 76-88, 2013.

CHRISTENSEN, Julia F. et al. Enhancing emotional experiences to dance through music: the role of valence and arousal in the cross-modal bias. Frontiers in Human Neuroscience, Lausanne, v. 8, n. 757, out. 2014.

CLARKE, Eric F. Creativity in performance. Musicae Scientiae, Thousand Oaks, v. 9, n. 1, p. 157-182, 2005.

Making and hearing meaning in performance. Nordic Journal of Aesthetics, Aarhus C, v. 18, n. 33-34, p. 24-48, 2006.

CSIKSZENTMIHALYI, Mihaly. Intrinsic rewards and emergent motivation in the hidden costs of reward: new perspectives on the psychology of human motivation. New York: Hillsdale, 1978. p. 205-2 16

COLE, J.; MONTERO, B. Affective proprioception. Janus Head, Pittsburgh, n. 9, p. 299-317, 2007.

DAHL, S; FRIBERG, A. (2007). Visual Perception of Expressiveness in Musicians' Body Movements. Music Perception 24 (5), 433-454, DOI: 10.1525/mp

D'AUSILIO, Alessandro. The role of the mirror system in mapping complex sounds into actions. Journal of Neuroscience, Washington, DC, v. 27, n. 22, p. 5847-5848, maio 2007. 
DAVIDSON, Jane W. Visual perception of performance manner in the movements of solo musicians. Psychology of Music, Thousand Oaks, $\vee 21$, n. 2, p. 103-113, 1993.

- Understanding the expressive performance movements of a solo pianist. Musikpsychologie, Berlin, v. 16, p. 7-29, 2002.

Bodily movement and facial actions in expressive musical performance by solo and duo instrumentalists: two distinctive case studies. Psychology of Music, Thousand Oaks, v. 40, n. 5, p. 595-633, 2012.

DAVIDSON, Jane W.; CORREIA, Jorge S. Body movement. In: PARNCUTT, Richard; MCPHERSON, Gary E. (Eds.) The science and psychology of music performance. New York: Oxford University Press, 2002. p 237-253.

DE MANZANO, O.; THEORELL, T.; HARMAT, L.; ULLEN, F. The psychophysiology of flow during piano playing. Emotion - American Psychological Association, Amherst, v. 10, n. 3, p. 301-311, 2010.

DEMOS, Alexander P.; CHAFFIN, Roger; KANT, Vivek. Toward a dynamical theory of body movement in musical performance. Frontiers in Psychology, Lausanne, v. 5, n. 477, maio 2014.

DI DIO, Cinzia et al. Human, nature, dynamism: the effects of content and movement perception on brain activations during the aesthetic judgment of representational paintings. Frontiers in Human Neuroscience, Lausanne, v. 9, n. 705, jan. 2016.

FERRARI, Pier F.; RIZZOLATTI, Giacomo. Mirror neuron research: the past and the future. Philosophical Transactions of the Royal Society B: biological sciences, London, v. 369, n. 1644, 2014.

FISCHER, Agneta H.; MANSTEAD, Antony S. R.; ZAALBERG, Ruud. Social influences on the emotion process. European Review of Social Psychology, Abingdon, v. 14, n. 1, p. 171-201, 2003.

FREEDBERC, David; CALLESE, Vittorio. Motion, emotion and empathy in aesthetic experience. Trends in Cognitive Science, Kidlington, v. 11, n. 5, p. 197-203, maio 2007. 
FUJINAMI, Tsutomu; HIDAKA, Shohei; KASHYAP, Neeraj. Evaluating presence based on balance. In: INTERNATIONAL SYMPOSIUM ON PERFORMANCE SCIENCE, Kyoto, 2015. Abstracts... Kyoto: Ryukoku University, 2015. p. 129.

FURUYA, Shinichi; OSU, Rieko; KINOSHITA, Hiroshi. Effective utilization of gravity during arm downswing in keystrokes by expert pianists. Neuroscience, Amsterdam, v. 164, n. 2, p. 822-831, set. 2009.

FURUYA, Shinichi et al. Control of multi-joint arm movements for the manipulation of touch in keystroke by expert pianists. BMC Neuroscience, London, v. 11, n. 82, 2010.

CALLESE, Vittorio. The manifold nature of interpersonal relations: the quest for a common mechanism. Philosophical Transactions of the Royal Society B: biological sciences, London, v. 358, n. 1431 , p. 517-528, 2003.

GALLESE, Vittorio et al. Action recognition in the premotor cortex. Brain, London, v. I 19, n. 2, p. 593-609, 1996.

GERIG, Reginald R. Famous pianists and their technique. Washington, DC: Luce, 1974.

CIBSON, Crystal; FOLLEY, Bradley S.; PARK, Sohee. Enhanced divergent thinking and creativity in musicians: a behavioural and nearinfrared spectroscopy study. Brain and Cognition, New York, v. 69, n. I, p. 162-169, set. 2008.

GINCRAS, Bruno et al. Perceiving musical individuality: performer identification is dependent on performer expertise and expressiveness, but not on listener expertise. Perception, Thousand Oaks, v. 40, n. 10, p. $1206-1220,2011$.

GRACHTEN, Maarten; UIDMER, Gerhard. Linear basis models for prediction and analysis of musical expression. Journal of New Music Research, Abingdon, v. 41, n. 4, p. $311-322,2012$.

HASSON, Uri et al. Brain-to-brain coupling: a mechanism for creating and sharing social world. Trends in Cognitive Science, Kidlington, v. 16, n. 2, p. 114-121. fev. 2012. 
IANNONE, Alejandra E. Music and motion. American Society for Aesthetics Graduate E-journal, [S. I.], v. 3, n. 1, p. 1-10, inverno 2011.

JABBI, Mbemba; SUART, Marte; KEYSERS, Christian. Empathy for positive and negative emotions in the gustatory cortex. Neurolmage, Orlando, v. 34, n. 4, p. 1744-1753, fev. 2007.

JIA, Lina. Crossmodal emotional modulation of time perception. 2013. Dissertação (PhD em Filosofia) - Ludwig-Maximilians-Universität, München, 2013.

JUCHNIEUICZ, Jay. The influence of physical movement on the perception of musical performance. Psychology of Music, Thousand Oaks, v. 36, n. 4, p. 417-427, 2008.

KOELSCH, Stefan. Brain correlates of music-evoked emotions. Nature Reviews: neuroscience, London, v. 15, n. 3, p. 170-180, 2014.

KUBOVY, M.; SCHUTZ, M. Causality and objects in vision and audition. Review of Philosophy and Psychology, Chicago, v. 1, n. 1, p. 41-61, 2010.

MANZANO, Örjan et al. The psychophysiology of flow during piano playing. Emotion, Washington, DC, v. 10, n. 3, p. 301-311, 2010.

MCPHERSON, Gary E. Musical prodigies: early manifestations, catalysts and outcomes. In: INTERNATIONAL SYMPOSIUM ON PERFORMANCE SCIENCE, Kyoto, 2015. Abstracts... Kyoto: Ryukoku University, 2015. p. 22.

MACRITCHIE, Jennifer. The art and science behind piano touch: a review connecting multi-disciplinary literature. Musicae Scientiae, Thousand Oaks, v. 19, n. 2, p. 171-190, 2015.

MAES, Pieter-Jan et al. Action-based effects on music perception. Frontiers in Psychology, Lausanne, v. 4, n. 1008, jan. 2014.

MARCULIS, Elizabeth H. Silences in music are musical not silent: an exploratory study of context effects on the experience of musical pauses. Music Perception, Berkeley, v. 24, n. 5, p. 485-506, jun. 2007. 
MASAKI, Megumi et al. Piano performance assessment: video feedback and the quality assessment in music performance inventory. In: INTERNATIONAL SYMPOSIUM ON PERFORMANCE SCIENCE, 2011, Toronto. Proceedings... Brussels: European Association of Conservatoires, 201 1. p. 503-508.

MONTERO, Barbara. Proprioception as an aesthetic sense. The Journal of Aesthetics and Art Criticism, Hoboken, v. 64, n. 2, p. $231-242$, primavera 2006.

OVERY, Katie; MOLNAR-SZAKACS, Istvan. Being together in time: musical experience and the mirror neuron system. Music Perception, Berkeley, v. 26, n. 5, p. 489-504, jun. 2009.

Music performance. Annual Review of Psychology, Palo Alto, v. 48, p. $115-138$, fev. 1997.

PLATZ, Friedrich. The influence of performers' stage entrance behavior on the audience's performance elaboration. In: INTERNATIONAL SYMPOSIUM ON PERFORMANCE SCIENCE, Vienna, 2013. Proceedings... Brussels: European Association of Conservatoires, 2013. p. 345-352.

REIMER, Jamie. The effect of the pre-performance talk on audience understanding and enjoyment. In: INTERNATIONAL SYMPOSIUM ON PERFORMANCE SCIENCE, Kyoto, 2015. Abstracts... Kyoto: Ryukoku University, 2015. p. 27.

REPP, Bruno H. Dynamics of expressive piano performance: Schumann's "Träumerei" revisited. Journal of the Acoustical Society of America, Melville, v. 100, n. 1, p. $641-650,1992$.

REPP, B. Music as motion: a synopsis of Alexander Truslit's (1938) "Cestaltung und Bewegung in der Musik". Psychology of Music, Londres, n. 21, p. 48-72, 1993.

Music as motion: a synopsis of Alexander Truslit's (1938) "Cestaltung und bewegung in der musik". Psychology of Music, Thousand Oaks, v. 21 , n. 1, p. 48-72, jan. 1993. 
RODCER, Matthew W. M.; CRAIC, Cathy M.; O'MODHRAIN, Sile. Expertise is perceived from both sound and body movement in musical performance. Human Movement Science, Amsterdam, v. 31, n. 5, p. 1137-1150, out. 2012.

SCHMIDT, Richard A.; LEE, Timothy D. Motor control and learning: a behavioral emphasis. Champaign: Human Kinetics, 2005.

SCHONBERG, Harold C. Do today's pianists have the romantic touch? The New York Times, New York, 1986. Disponivel em: <https://goo.gl/sXBx9u>. Acesso em: 2 abr. 2018.

SCHUTZ, Michael; LIPSCOMB, Scott. Hearing gestures, seeing music: vision influences perceived tone duration. Perception, Thousand Oaks, v. 36, n. 6, p. 888-897, jun. 2007.

SEASHORE, Carl E. Psychology of music. New York: McCraw-Hill, 1938.

SHODA, Haruka; ADACHI, Mayumi. Effects of the listening context on the audience's perceptions of artistry, expressiveness, and affective qualities in the piano performance: a single case study. Music Perception, Berkeley, v. 29, n. 3, p. 237-254, 2012.

SHOUSE, Eric. Feeling, emotion, affect. M/C Journal, Kelvin Grove, v. 8, n. 6, dez. 2005. Disponível em: <https://goo.gl/EFlgA>. Acesso em: 2 abr. 2018.

THOMPSON, William F. Mapping acoustic cues onto facial expressions. In: INTERNATIONAL SYMPOSIUM ON PERFORMANCE SCIENCE, Toronto, 2011. Proceedings... Brussels: European Association of Conservatoires, 2011 . p. 163-169.

THOMPSON, William F.; CRAHAM, Phil; RUSSO, Frank A. Seeing music performance: visual influences on perception and experience. Semiotica, La Haye, v. 2005, n. 156, p. 203-227, 2005.

TSAY, Chia-Jung. Sight over sound in the judgment of music performance. Proceedings of the National Academy of Sciences of the United States of America, Washington, DC, v. 1 10, n. 36, p. 14580-14585, 2013. 
VAN DER SCHYFF, Dylan. Emotion, embodied mind and the therapeutic aspects of musical experience in everyday life. Approaches: music therapy \& special music education, Athens, v. 5, n. 1, 2013.

VILA VERDE, Teresa. Assessing the importance of visual/theatrical features in the perception of music by an audience, using sociological tools. In: INTERNATIONAL SYMPOSIUM ON PERFORMANCE SCIENCE, Porto, 2007. Proceedings... Brussels: European Association of Conservatoires, 2007. p. $147-153$.

VINES, Bradley W. et al. Music to my eyes: cross-modal interactions in the perception of emotions in musical performance. Cognition, Amsterdam, v. 118, n. 2, p. 157-170, fev. 2011.

VUOSKOSKI, J. K.; THOMPSON, M. R.; CLARKE, E. F.; SPENCE, C. Crossmodal interactions in the perception of expressivity in musical performance. Attention, Perception \& Psychophysics, Nova York, v. 76, n. 2, p. 591-604, 2014.

WADDELL, George; UILLIAMSON, Aaron. Time to decide: the effects of extra-musical variables on continuous ratings of performance quality. In: INTERNATIONAL SYMPOSIUM ON PERFORMANCE SCIENCE, Kyoto, 2015. Abstracts... Kyoto: Ryukoku University, 2015. p. 94.

WANDERLEY, Marcelo M. et al. The musical significance of clarinetists' ancillary gestures: an exploration of the field. Journal of New Music Research, Abingdon, v. 34, n. 1, p. 97-113, 2005.

WAPNICK, Joel et al. Effects of non-musical attributes and excerpt duration on ratings of high-level piano performances. Musicae Scientiae, Thousand Oaks, v. 13, n. 1, p. 35-54, 2009.

WEBSTER, Peter R. Creativity as creative thinking. Music Educators Journal, Thousand Oaks, v. 76, n. 9, p. 22-28, maio 1990.

ZATORRE, Robert J. Beyond auditory cortex: working with musical thoughts. Annals of the New York Academy of Sciences, New York, v. 1252, n. I, p. 222-228, abr. 2012. 
ZATORRE, Robert J.; SALIMPOOR, Valorie N. From perception to pleasure: music and its neural substrates. Proceedings of the National Academy of Sciences of the United States of America, Washington, DC, v. 110, n. 2, p. 10430-10437, 2013.

\section{About the author}

Barbara James completed her PhD in biomechanics and functional anatomy in the School of Human Movement and Nutrition Sciences at the University of Queensland. Subsequently she worked for the Queensland Government in the Department dealing with the occupational concerns of workers in industry and writing codes of practice on the prevention of injury caused by manual tasks in industry. She worked subsequently as a consultant to the Australian Academy of Sport writing documents on the legal and medical obligations for sports bodies conducting sport for junior players, and for the Queensland Academy of Sport supervising students undertaking $\mathrm{PhD}$ research related to injuries in elite athletes. Her research interest in piano performance includes injury prevention in pianists, and risk management in music conservatoria and the recently established neural link between pianists and audience. 